\title{
PENGELOLAAN DAN PEMANFAATAN SUMBER DAYA MINERAL BERWAWASAN LINGKUNGAN (Studi Kasus Kabupaten Halmahera Utara)
}

\author{
Aliyusra Jolo 1, Rudi S. Gautama *2 \\ ${ }^{1}$ Program Magister Rekayasa Pertambangan, Fakultas Teknik Pertambangan dan Perminyakan, ITB, \\ Kelompok Keahlian Lingkungan Tambang, Email : 1hio_mining@yahoo.co.id \\ 2 Pasca Sarjana Rekayasa Pertambangan-ITB, Kelompok Keahlian Lingkungan tambang, Jl. Ganesha no. \\ 10 Bandung. \\ *Corresponding Author: ukarws@yahoo.com, arwi.mining@itb.ac.id; \\ Manuscript received: 20-03-2018 Revision accepted: 28-05-2018
}

\begin{abstract}
Abstrak
Keterdapatan potensi sumber daya mineral mempunyai peran strategis untuk mempercepat laju pembangunan di Kabupaten Halmahera Utara dimana status wilayah dalam katogori daerah tertinggal. Pengelolan potensi sumberdaya mineral yang dieksploitasi tentu mempunyai tantangan yang cukup berat karena pada wlilayah izin usaha pertambangan terdapat potensi sumber daya alam lainnya seperti kehutanan, kawasan pertanian dan kelautan. Pengoptimalan potensi sumberdaya mineral diperlukan kajian lingkungan hidup strategis untuk menetukan arah kebijakan pengelolaan kegiatan pertambangan sehingga diharapakan dapat meminimaliskan potensi pencemaran dampak negatif lingkungan. Pengelolaan sumberdaya mineral juga mampu meningkatkan pertumbuhan ekonomi sektor lainnya, sehingga mempercepat laju pembangunan daerah disamping meminimalkan potensi dampak lingkungan sehingga manfaat dari sumberdaya mineral dapat dioptimalkan. Oleh karenanya perlu menentukan arah kebijakan pengelolaan potensi sumberdaya mineral di Kabupaten Halmahera Utara yang berwawasan lingkungan. Kondisi eksisting di Kabupaten Halmahera Utara menunjukan hampir seluruh wilayah daratan merupakan kawasan hutan dengan persentase $87 \%$, sedangkan sisanya adalah Areal Penggunaan Lain (APL). Selain itu, dalam megeksploitasi potensi sumberdaya mineral juga berdampak terhadap kelautan dan spesies endemik serta pendapatan nelayan. Arah kebijakan pengelolaan lingkungan hidup kegiatan pertambangan emas meliputi pembatasan luas bukaan sehingga ekosistem lokal terjaga, Pengelolaan air asam tambang dengan water management, serta limbah pengolahan bijih perlu diproses dengan detoksifikasi. Arah kebijakan pengelolaan lingkungan hidup kegiatan pertambangan Nikel meliputi pembatasan luas bukaan sehingga potensi erosi dapat berkurang, pengelolaan air dengan melakukan water management dan pengelolaan lahan bekas tambang. Arah kebijakan pengelolaan lingkungan hidup kegiatan pertambangan Mangan meliputi pembatasan luas bukaan sehingga potensi erosi di Pulau Doi Kecamatan Loloda Kepulauan dan erosi di Kecamatan Loloda Utara serta Galela Utara dapat dikurangi, pengelolaan air dengan water management, pengolahan tailing dilakukan dengan lapisan air permanen, cladding dan capping serta pengelolaan lahan bekas tambang. Arah kebijakan pengelolaan lingkungan hidup kegiatan pertambangan pasir besi diantaranya pencegahan abrasi dengan melakukan penanaman mangrove, budidaya terumbu karang dan pembuatan tanggul penahan ombak, penambahan atau penetapan daerah perlindungan dan penguatan status konservasi untuk melindungi spesies burung mamua di Kecamatan Galela Utara, membatasi perizinan eksploitasi pertambangan di sempadan pantai serta pemberdayaan masyarakat nelayan.
\end{abstract}

Kata Kunci: APL, Halmahera Utara, pertambangan, water management, tailing 


\section{PENDAHULUAN}

Industri pertambangan merupakan suatu bidang usaha dengan kegiatannya berpotensi menimbulkan perubahan pada rona lingkungan di sekitar aktifitas penambangan. Aktivitas industri pertambangan selalu berdampak pada dua sisi. Sisi pertama adalah untuk pembangunan dan kemakmuran ekonomi negara, sementara di sisi yang lainnya adalah potensi dampak kerusakan lingkungan. Kondisi ini juga diiringi oleh laju pertumbuhan penduduk, pesatnya pembangunan infrastruktur, pola hidup masyarakat yang cenderung konsumtif, terjadinya perubahan iklim, lemahnya penegakan hukum serta belum optimalnya kapasitas sumberdaya manusia dalam pengelolaan lingkungan hidup. Kabupaten Halmahera Utara merupakan salah satu Kabupaten yang masuk dalam katagori kawasan daerah tertinggal. Kabupaten Halmahera Utara yang merupakan daerah tertinggal, untuk itu perlu memanfaatkan potensi sumberdaya mineral demi mempercepat pembangunan daerah dan kesejateraan masyarakat Halmahera Utara. Dengan demikian dalam proses pengelolaan potensi sumber daya mineral tersebut di harapkan seoptimal mungkin, untuk dapat mengoptimalkan potensi sumber daya mineral maka diupayakan potensi dampak negatif terhadap lingkungan hidup kegiatan pertambangan mineral dapat di minimalisir.

\section{METODOLOGI PENELITIAN}

Metode penelitian yang dipakai pada penelitian ini adalah analisis deskriptif dengan pendekatan Kajian Lingkungan Hidup Strategis. KLHS merupakan bagian dari keselurahan kajian lingkungan hidup (environmental assesment), yang dalam konteks proses pengambilan keputusan pembangunan, dimanfaatkan mulai dari perumusan kebijakan, rencana dan program. Sifat kajian terhadap aspek kebijakan, aspek regional, aspek programatik dan aspek sektoral. Sedangkan untuk AMDAL, implementasinya adalah pada tingkat proyek. Ruang lingkup studi KLHS dalam suatu pengambilan keputusan dapat dilihat pada gambar dibawah

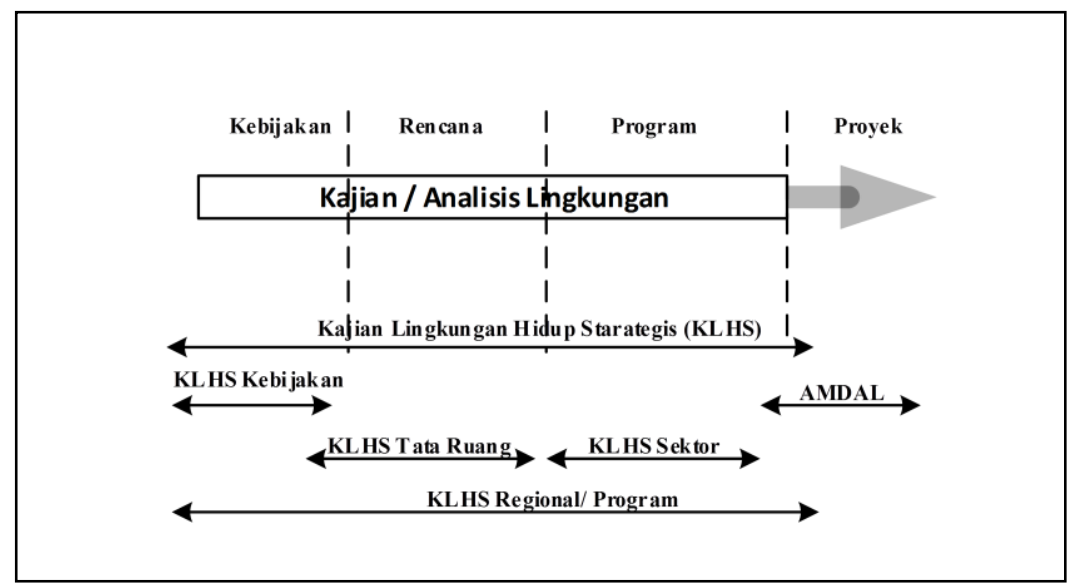

Gambar 1. Ruang Lingkup Studi KLHS

\section{KONDISI WILAYAH}

\section{a. Administratif}

Secara administratif luas keseluruhan wilayah Kabupaten Halmahera Utara adalah 22.507,32 kilometer persegi yang terdiri dari laut seluas lebih $19.375,02 \mathrm{~km}^{2}(86,09 \%)$, sedangkan luas 
daratan adalah 3.132,30 km² (13,91\%). Saat ini Kabupaten Halmahera Utara terdiri dari 17 Kecamatan dan 196 desa. Kawasan terbangun adalah ruang dalam kawasan permukiman yang mempunyai ciri dominasi penggunaan lahan secara terbangun atau lingkungan binaan untuk mewadahi kegiatan daerah (Peraturan Menteri Pekerjaan Umum no. 20 tahun 2011 tentang Pedoman Rencana Detail Tata Ruang Kabupaten).

Tabel 1. Luas Wilayah Administratif Kab. Halmahera Utara

\begin{tabular}{|c|c|c|c|c|c|}
\hline & \multirow{3}{*}{ Kecamatan } & \multirow{3}{*}{$\underset{\text { Desa }}{\text { Jumlah }}$} & \multicolumn{3}{|c|}{ Luas Wilayah $\left(\mathrm{Km}^{2}\right)$} \\
\hline & & & \multicolumn{2}{|c|}{ Administrasi } & \multirow{2}{*}{$\begin{array}{c}\text { Terbangun } \\
\left(\mathrm{Km}^{2}\right)\end{array}$} \\
\hline & & & $\left(\mathrm{Km}^{2}\right)$ & $(\%)$ & \\
\hline \multicolumn{2}{|l|}{ Malifut } & 22 & 374,1 & 11.94 & 0,27 \\
\hline \multicolumn{2}{|l|}{ Kao } & 19 & 111,2 & 3.55 & 0,21 \\
\hline \multicolumn{2}{|c|}{ Kao Utara } & 11 & 128,8 & 4.11 & 0,20 \\
\hline \multicolumn{2}{|c|}{ Kao Barat } & 20 & 596,7 & 19.05 & 0,21 \\
\hline \multicolumn{2}{|c|}{ Kao Teluk } & 11 & 135,4 & 4.32 & 0,12 \\
\hline \multicolumn{2}{|c|}{ Tobelo } & 10 & 33 & 1.05 & 0,80 \\
\hline \multicolumn{2}{|c|}{ Tobelo Tengah } & 9 & 56 & 1.79 & 0,16 \\
\hline \multicolumn{2}{|c|}{ Tobelo Utara } & 11 & 100,4 & 3.21 & 0,27 \\
\hline \multicolumn{2}{|c|}{ Tobelo Selatan } & 13 & 204,3 & 6.52 & 0,35 \\
\hline \multicolumn{2}{|c|}{ Tobelo Timur } & 6 & 120 & 3.83 & 0,16 \\
\hline \multicolumn{2}{|c|}{ Tobelo Barat } & 5 & 294,7 & 9.41 & 0,14 \\
\hline \multicolumn{2}{|c|}{ Galela } & 6 & 138,7 & 4.43 & 0,17 \\
\hline \multicolumn{2}{|c|}{ Galela Utara } & 12 & 255,3 & 8.15 & 0,20 \\
\hline \multicolumn{2}{|c|}{ Galela Selatan } & 7 & 84,5 & 2.70 & 0,18 \\
\hline \multicolumn{2}{|c|}{ Galaela Barat } & 9 & 45,5 & 1.45 & 0,23 \\
\hline \multicolumn{2}{|c|}{ Loloda Utara } & 15 & 390,4 & 12.46 & 0,25 \\
\hline \multicolumn{2}{|c|}{ Loloda Kepulauan } & 10 & 63,3 & 2.02 & 0,19 \\
\hline \multirow{3}{*}{ Jumlah } & Daratan / Land & \multirow{2}{*}{196} & 3132,30 & 13,91 & 4,45 \\
\hline & Lautan / Sea & & 19375,02 & 86,09 & \\
\hline & $\begin{array}{l}\text { Luas Keseluruhan } \\
\text { Al1 }\end{array}$ & & $22.507,32$ & 100 & \\
\hline
\end{tabular}

\section{b. Rencana Pola Ruang}

Rencana pola ruang RTRW kabupaten Halmahera Utara berdasarkan PERDA kabupaten Halmahera Utara nomor: 09 tahun 2012 tentang Rencana Tata Ruang Wilayah kabupaten Halmahera Utara tahun 2012-2032, yang terdiri dari kawasan lindung dan kawasan budidaya. Untuk kawasan lindung tersebar di seluruh wilayah kabupaten Halmahera Utara terdapat di kecamatan Malifut, Kao Barat, Tobelo, Galela, Galela Barat dan kecamatan Loloda Utara serta kecamatan Galela Utara, sedangkan untuk kawasan budidaya meliputi kawasan hutan produksi terbatas, kawasan hutan produksi tetap dan kawasan hutan produksi konversi, kawasan pertanian dan kawasan pemukiman. Kawasan budidaya juga tersebar di seluruh wilayah kabupaten Halmahera Utara.

\section{ISU STRATEGIS LINGKUNGAN HIDUP}

\section{a. Tumpang Tindih Kawasan Pertambangan Mineral dan Kawasan Hutan}

Tumpang tidih sektor pertambangan dalam kawasan hutan lindung terdapat pada izin usaha pertambangan emas sebanyak 6 (enam) IUP yaitu PT Nusa Halmahera Mineral, PT Addis Pratama Perkasa, PT Halmahera Jaya Mineral, PT Nusantara Timur Mineral dan 2 (dua) IUP mineral emas PT Hibualamo Jaya. 
Dari penjelasan tumpang tindih kawasan hutan terhadap izin usaha pertambangan dapat disimpulkan bahwa terdapat tumpang tidih kawasan hutang lindung terhadap izin usaha pertambangan emas. Apabila kegiatan pertambangan emas dilakukan dengan metode tambang terbuka maka berpotensi dampak penting yaitu berkurang bahkan punahnya biota endemik selain itu berpotensi terhadap pencemaran air. Tumpang tindih izin usaha pertambangan mineral terhadap kawasan hutan dapat di lihat Tabel 2.

Tabel 2. Luas Tumpang Tindih Kawasan Pertambangan Dalam Kawasan Hutan

\begin{tabular}{|c|c|c|c|c|c|c|c|}
\hline \multirow[b]{2}{*}{ No } & \multirow{2}{*}{ Nama Perusahaan } & \multirow{2}{*}{ Mineral } & \multirow{2}{*}{$\begin{array}{c}\text { Luas } \\
\text { wilayah } \\
\text { IUP (Ha) }\end{array}$} & \multicolumn{4}{|c|}{ Luas tumpang tindih lahan (Ha) } \\
\hline & & & & HPT & HPK & HL & HP \\
\hline $\mathbf{1}$ & PT. Mineral Elok Sejatera & Mangan & 834,55 & 767,37 & & & \\
\hline 2 & PT. Elga Astra Media & Mangan & $1.000,00$ & 971,50 & 28,50 & & \\
\hline 3 & PT. Putra Pangestu & Mangan & $1.891,11$ & 811,10 & 975,06 & & \\
\hline 4 & PT. Putra Waihetu Mineral & Mangan & $2.505,80$ & $1.569,63$ & 379,88 & & \\
\hline 5 & PT. Global Digital Nusantara & Mangan & $2.036,65$ & $1.676,57$ & 31,98 & & \\
\hline 6 & PT. Proindo Plus & Mangan & $2.025,18$ & $1.072,54$ & 277,45 & & \\
\hline 7 & PT. Halmahera Sentara Mineral & Pasir Besi & $1.500,00$ & & 68,55 & & \\
\hline 8 & PT. Indonesia Bina Mineral & Pasir Besi & $1.587,53$ & & & & \\
\hline 9 & PT. Infiniti Pacifik Mining & Mangan & $2.634,84$ & & 493,24 & & 167,84 \\
\hline 10 & PT. Hibualamo Jaya & emas & $5.000,00$ & $2.607,50$ & 153,50 & 131,50 & $1.821,00$ \\
\hline 11 & PT. Adya Karya Gemilang & Mangan & 321,27 & 160,64 & & & 160,60 \\
\hline 12 & PT. Adya Karya Gemilang & Mangan & 248,61 & 209,98 & 13,00 & & \\
\hline 13 & PT. Karya Intan Maksima & Pasir Besi & 2237,37 & & & & \\
\hline 14 & PT. Amo Ngajama & Pasir Besi & $1.300,00$ & & & & \\
\hline 15 & PT. Addis Pratama Perkasa & Pasir Besi & $3.054,02$ & & 653,56 & & $1.017,90$ \\
\hline 16 & PT. Addis Pratama Perkasa & Emas & 7419,81 & & 135,04 & $2.699,33$ & $1.022,45$ \\
\hline 17 & PT. Indonesia Bina Mineral & Pasir Besi & 399,97 & & & & \\
\hline 18 & PT. Sumber Ardi Swarna & Pasir Besi & $1.544,00$ & & 26,40 & & \\
\hline 19 & PT. Intim Resources & Pasir Besi & 858,19 & & & & \\
\hline 20 & PT. Wirabudi Putra Perkasa & Pasir Besi & 1871,81 & & 453,91 & & \\
\hline 21 & PT. Hibualamo Jaya & Emas & 12889,61 & & $2.875,67$ & & $4.511,36$ \\
\hline 22 & PT. Halmahera Jaya Mineral & Emas & $1.500,00$ & & 159,75 & 266,70 & 846,75 \\
\hline 23 & PT. Bumi Nusantara Timur Mineral & Emas & $3.560,00$ & & $3.204,00$ & 176,22 & \\
\hline 24 & PT. Labindo Nusa Persada & Nikel & $3.607,04$ & & & & \\
\hline 25 & PT. Hibualamo Jaya & Emas & $15.668,11$ & $10.452,20$ & 278,89 & $3.290,30$ & \\
\hline 26 & PT. Triwira Adipermana Pratama & Emas & $12.168,28$ & 2967,84 & $5.354,04$ & & \\
\hline 27 & PT. Triwira Adipermana Pratama & Emas & $2.831,89$ & $1.572,83$ & $1.047,80$ & & \\
\hline 28 & PT. Ksu Beringin Jaya & Emas & $1.706,47$ & 70,31 & $1.375,24$ & & \\
\hline 29 & PT. Terrarex Lumina jaya & Emas & $9.234,11$ & & $3.664,09$ & & \\
\hline 30 & PT. Nusa Halmahera Mineral & Emas & $29.622,00$ & $10.563,21$ & $4.822,46$ & $7.482,52$ & \\
\hline Total & & & 133.058,22 & $35.473,20$ & $26.472,03$ & 14.046,57 & $9.547,91$ \\
\hline
\end{tabular}

\section{b. Tumpang Tindih Kawasan Pertambangan dan Pertanian}

Adapun luas kawasan pertanian yang terdapat dalam kawasan izin usaha pertambangan perkomoditas mineral adalah sebagai berikut:

a) Emas

Izin usaha pertambangan (IUP) mineral emas di dalam kawasan pertanian terdapat 8 (delapan) dari 12 wilayah izin usaha pertambangan mineral emas. Wilayah tumpang tindih terdapat pada PT Hibualamo Jaya, PT Addis Pratama Perkasa seluas , PT Wirabudi Putra Perkasa PT Triwira Adepermana Pratama, Ksu Beringin Jaya, Terrarex Lumina Jaya dan PT Nusa Halmahera Mineral. Wilayah tumpang tindih terhadap kawasan pertanian terluas berada pada PT Nusa Halmahera Mineral sebesar 5.934,40 Ha dan PT Terrarex Lumina Jaya seluas 4.152,87 ha. 
b) Nikel

Pada kawasan IUP mineral nikel yang berada dalam kawasan pertanian terdapat PT Labindo Nusa Persada dengan luas tumpang tindih sebesar 2582,23 ha.

c) Mangan

Pada kawasan IUP mineral mangan dalam kawasan pertanian terdapat 4 (empat) dari 9 (sembilan) IUP yang tumpang tindih diantaranya PT Putra Waihetu Mineral, PT Global Digital Nusantara, PT Proindo Plus dan PT Infiniti Pacifik Mining. Luas tumpang tindih kawasan pertanian terluas berada pada PT Proindo Plus sebesar 990,48 ha dan PT Global Digital Nusantara seluas 663,35 ha.

d) Pasir besi

Wilayah IUP mineral pasir besi yang berada dalam kawasan pertanian terdapat PT Halmahera Sentra Mineral, PT Amo Ngajama, PT Addis Pratama Sejatera dan PT Wirabudi Putra Perkasa. Luas tumpang tindih izin usaha pertambangan mineral pasir besi dalam kawasan pertanian terluas terdapat pada PT Addis Pratama seluas 1.872,33 ha dan PT Amo Ngajama seluas 260,45 ha.

Berdasarkan tumpang tindih wilayah izin usaha pertambangan mineral dalam kawasan pertanian, terdapat tumpang tindih lahan sebesar 25.892,7 (33\%) ha dari luas total lahan pertanian di kabupaten Halmahera Utara (77.922 Ha). Tumpang tindih wilayah izin usaha pertambangan mineral terhadap lahan pertanian dengan pemakaian lahan terbesar didominasi oleh IUP emas. Cebakan emas merupakan emas primer yang melakukan penambangan dengan metode tambang bawah tanah sehingga tidak berdampak penting. Luas tumpang tindih izin usaha pertambangan mineral dalam kawasan pertanian dapat dilihat pada Tabel 3. 
Tabel 3. Luas Tumpang Tindih Kawasan Pertambangan Dalam Kawasan Hutan

\begin{tabular}{|c|c|c|c|c|}
\hline No & Nama Perusahaan & Mineral & $\begin{array}{c}\text { Luas } \\
\text { wilayah } \\
\text { IUP (Ha) } \\
\end{array}$ & $\begin{array}{l}\text { Luas tumpang tindih } \\
\text { lahan pertanian (Ha) }\end{array}$ \\
\hline $\mathbf{1}$ & PT. Mineral Elok Sejatera & Mangan & 834,55 & \\
\hline 2 & PT. Elga Astra Media & Mangan & $1.000,00$ & \\
\hline 3 & PT. Putra Pangestu & Mangan & $1.891,11$ & \\
\hline 4 & PT. Putra Waihetu Mineral & Mangan & $2.505,80$ & 297,94 \\
\hline 5 & PT. Global Digital Nusantara & Mangan & $2.036,65$ & 663,35 \\
\hline 6 & PT. Proindo Plus & Mangan & $2.025,18$ & 990,48 \\
\hline 7 & PT. Halmahera Sentara Mineral & Pasir Besi & $1.500,00$ & 208,63 \\
\hline 8 & PT. Indonesia Bina Mineral & Pasir Besi & $1.587,53$ & o \\
\hline 9 & PT. Infiniti Pacifik Mining & Mangan & $2.634,84$ & 560,13 \\
\hline 10 & PT. Hibualamo Jaya & emas & $5.000,00$ & 283,05 \\
\hline 11 & PT. Adya Karya Gemilang & Mangan & 321,27 & \\
\hline 12 & PT. Adya Karya Gemilang & Mangan & 248,61 & \\
\hline 13 & PT. Karya Intan Maksima & Pasir Besi & 2237,37 & \\
\hline 14 & PT. Amo Ngajama & Pasir Besi & $1.300,00$ & 260,45 \\
\hline 15 & PT. Addis Pratama Perkasa & Pasir Besi & $3.054,02$ & $1.872,33$ \\
\hline 16 & PT. Addis Pratama Perkasa & Emas & 7419,81 & 932,32 \\
\hline 17 & PT. Indonesia Bina Mineral & Pasir Besi & 399,97 & \\
\hline 18 & PT. Sumber Ardi Swarna & Pasir Besi & $1.544,00$ & \\
\hline 19 & PT. Intim Resources & Pasir Besi & 858,19 & \\
\hline 20 & PT. Wirabudi Putra Perkasa & Pasir Besi & 1871,81 & 234,74 \\
\hline 21 & PT. Hibualamo Jaya & Emas & 12889,61 & $2.464,56$ \\
\hline 22 & PT. Halmahera Jaya Mineral & Emas & $1.500,00$ & \\
\hline 23 & PT. Bumi Nusantara Timur Mineral & Emas & $3.560,00$ & \\
\hline 24 & PT. Labindo Nusa Persada & Nikel & $3.607,04$ & $2.582,23$ \\
\hline 25 & PT. Hibualamo Jaya & Emas & $15.668,11$ & 0,00 \\
\hline 26 & PT. Triwira Adipermana Pratama & Emas & $12.168,28$ & $4.076,23$ \\
\hline 27 & PT. Triwira Adipermana Pratama & Emas & $2.831,89$ & \\
\hline 28 & PT. Ksu Beringin Jaya & Emas & $1.706,47$ & 378,95 \\
\hline 29 & PT. Terrarex Lumina jaya & Emas & $9.234,11$ & $4.152,87$ \\
\hline 30 & PT. Nusa Halmahera Mineral & Emas & $29.622,00$ & $5.934,40$ \\
\hline \multicolumn{3}{|c|}{$\begin{array}{c}\text { Total } \\
\end{array}$} & $133.058,22$ & $25.892,7$ \\
\hline
\end{tabular}

\section{c. Pertambangan Terhadap Perikanan \& Kelautan}

Adapun potensi dampak yang ditimbulkan baik langsung maupun tidak langsung adalah sebagai berikut :

a) Dampak langsung

Dampak langsung terjadi pada kegiatan pertambangan pasir besi yang pada umumnya lokasi kegiatan pertambangan berada pada wilayah pesisir pantai dan di laut. Adapun wilayah izin usaha pertambangan tersebut yaitu PT Halmahera Sentra Mineral, PT Indonesia Bina Mineral, PT Karya Intan Maksima, PT Amo Ngajama, PT Addis Pratama Sejatera, PT Indonesia Bina Mineral, PT Sumber Ardi Swarna, PT Intim Resource dan PT Wirabudi Putra Perkasa.

b) Dampak tidak langsung

Dampak tidak langsung merupakan dampak yang disebabkan oleh kegiatan pertambangan yang wilayah izin usaha pertambangan berada jauh dari pesisir pantai dan laut sehingga pencemaran terjadi dari proses transportasi melalui sungai yang masuk ke laut. 


\section{d . Pertambangan Mineral Terhadap Spesies Endemik}

Spesies endemik di Kabupaten Halmahera Utara tersebar sebagai berikut:

Di wilayah selatan Kabupaten Halmahera Utara, tepatnya pada lokasi izin usaha pertambangan mineral emas terdapat spesies endemik Burung Bidadari dan burung Kakatua Putih serta burung Nuri Bayan. Pembukaan lahan tidak terlalu signifikan sehingga spesies endemik pada daerah tersebut tidak berpotensi berkurang ataupun punah. Spesies burung Nuri Bayan terdapat di Kecamatan Galela Barat tepatnya di wilayah izin usaha pertambangan mineral emas, juga tidak berdampak signifikan. Di kecamatan Galela dan Kecamatan Galela Barat terdapat burung Mamoa yang merupakan wilayah izin pertambangan mineral pasir besi. Metode penambangan dengan menggunakan kapal keruk dapat menyebabkan abrasi sehingga dapat mengancam kepunahan spesies tersebut yang menggunakan pantai sebagai tempat bertelur bagi burung Mamoa. Di pulau Tobo-Tobo terdapat kelelawar buah. Daerah tersebut merupakan daerah yang berdekatan dengan wilayah konsesi mineral pasir besi.

\section{e. Dampak Positif Ekonomi Dan Sosial Kegiatan Pertambangan di Kabupaten Halmahera Utara}

1) Sumbangan pihak ketiga PT Nusa Halmahera Mineral

Kontribusi perusahan pertambangan terhadap pembangunan daerah di tunjukan PT Nusa Halmahera Mineral dengan memberikan sumbagan terhadap pemerintah daerah Kabupaen Halmahera Utara sebesar Rp 86.175.000.000,- (SKPD Halmahera Utara 2014).

2) Dana bagi Hasil SDA pertambangan umum

Dana bagi hasil dari penerimaan negara iuran tetap (land-rent) yang menjadi bagian daerah dibagi dengan rincian $16 \%$ (enam belas persen) untuk provinsi yang bersangkutan; dan 64\% (enam puluh empat persen) untuk kabupaten/kota penghasil. Dana bagi hasil dari penerimaan negara iuran eksplorasi dan iuran eksploitasi (royalti) yang menjadi bagian daerah dibagi dengan rincian: 16\% (enam belas persen) untuk provinsi yang bersangkutan; 32\% (tiga puluh dua persen) untuk kabupaten/kota penghasil; dan 32\% (tiga puluh dua persen) untuk kabupaten/kota lainnya dalam provinsi yang bersangkutan. Bagian kabupaten/kota dibagikan dengan porsi yang sama besar untuk semua kabupaten/kota dalam provinsi yang bersangkutan. Dana bagi hasil sumber daya alam pertambangan umum di Kabupaten Halmahera Utara tahun 2014 sebesar Rp15.757.000.000,- (SKPD Halmahera Utara 2014)

3) Tenaga kerja sektor pertambangan mineral

Sektor pertambangan umum di Kabupaten Halmahera Utara menyerab tenaga kerja sebanyak 2.774 orang tahun 2013 (Dinas Ketenagakerjaan Pemerintah daerah Halmahera Utara)

4) Tanggung jawab sosial masyarakat (Corporate Social Responsibility)

Corporate Social Responsibility (CSR) merupakan bentuk tanggung jawab sosial dari perusahaan kepada mayarakat dengan membawa sustainability development, bahwa pembangunan berkelanjutan adalah pembangunan yang dapat memenuhi kebutuhan manusia saat ini tanpa mengorbankan kemampuan generasi yang akan datang dalam memenuhi kebutuhan mereka (masyarakat).

5) Efek ganda (multi player effect)

Kehadiran perusahaan pertambangan disuatu daerah membutuhkan banyak input dari sektor-sektor lain. Semakin banyak perusahaan tambang memeberikan kepercayaan kepada pengusaha lokal untuk memenuhi input-input produksinya, maka semakin 
besar manfaat yang dapat diterima. Secara teori, nilai ekonomi merupakan akumulasi dari tiga variabel ekonomi yaitu : imbalan ekonomi (economic rent) berupa keuntungan langsung, kelebihan pembayaran (excess payment) dan berbagai macam keterkaitan atau linkages (Bulmer, 1998) antara lain : keterkaitan hulu, hilir, teknologi, pembayaran pajak dan kebutuhan akhir (final demand).

\section{PEMBAHASAN}

\section{Karakteristik Cebakan Mineral dan Teknik Pengolahan}

\section{1) Emas}

Cebakan mineral emas tersebar di beberapa wilayah Kabupaten Halmahera Utara. Sebaran cebakan mineral emas tersebar pada tiga wilayah sebagai berikut:

a. Wilayah Selatan Kabupaten Halmahera Utara di Kecamatan Kao, Malifut, Kao Teluk dan Kecamatan Kao Barat

b. Wilayah Tengah Kabupaten Halmahera Utara di Kecamatan Galela Barat

c. Wilayah Utara Kabupaten Halmahera Utara di Kecamatan Loloda Utara.

Berdasarkan karakteristik endapan emas tersebut, kegiatan penambangan dilakukan dengan metode tambang bawah tanah (cut and fill) dan tambang terbuka (open pit). PT Nusa Halmahera Mineral melakukan kegiatan pertambangan mineral menggunakan kedua metode penambangan tersebut. Adapun tahapan penambangan pada kedua metode tersebut adalah sebagai berikut:

Open pit

PT. Nusa Halmahera Mineral melakukan penambangan terbuka dengan metode Open pit mining. Adapun proses penambangan adalah sebagai berikut:

1) Melakukan pembukaan lahan yaitu pembersihan lahan permukaan dengan penebangan pohon.

2) Selanjutnya melakukan pemisahan overburden yang ditempatkan pada disposal.

3) Setelah itu di lakukan pengeboran untuk pengisian bahan peledak pada batuan dan kemudian di ledakkan menjadi material lepas.

4) Selanjutnya dilakukan pengangkutan.

5) Ore kemudian disimpan pada stokpile.

6) Pengolahan bijih.

\section{2) Nikel}

Berdasarkan karakteristik tersebut sehingga penambangan nikel dilakukan dengan metode tambang terbuka (open cast).

Open cast mining, metodanya hampir sama dengan open pit mining, tetapi berbeda pada satu hal yaitu tanah penutup tidak dibuang ke daerah pembuangan di luar tambang tetapi dibuang langsung ke lokasi bersebelahan yang telah ditambang. Tahapan aktivitas penambangan nikel di Kabupaten Halmahera Timur dengan tahapan sebagai berikut:

1. pembersihan lahan (clearing)

2. pemisahan lapisan penutup (topsoil)

3. penggalian 
4. pengangkutan

5. pemisah crusher ukuran pada saat dumping dengan alat jaw crusher

6. stockpile

7. pengapalan.

\section{3) Mangan}

Berdasarkan karakteristik maka endapan mineral mangan tersebut merupakan endapan sekunder, sehingga metode penambangan menggunakan metode tambang terbuka (open cast). Adapun tahapan penambangan cebakan mangan adalah sebagai berikut:

1. pembersihan lahan (clearing)

2. pemisahan lapisan penutup (topsoil)

3. penggalian

4. pengangkutan

5. ukuran pada saat dumping dengan alat jaw crusher

6. stockpile

7. pengolahan pemisahan bijih.

\section{4) Pasir Besi}

Berdasarkan karakteristik endapan pasir besi tersebut, sehingga penambangan dilakukan di darat dengan metode tambang terbuka (alluvial) dan di laut menggunakan metode kapal keruk.

1. Tambang Alluvial

Metode tambang alluvial adalah tambang terbuka yang diterapkan untuk menambang endapan-endapan alluvial, misalnya tambang bijih timah, pasir besi, dan lain-lain. Penambangan pasir besi di darat menggunakan alat muat (truk) dan alat gali (shovel) .

2. Kapal keruk

Berdasarkan macam alat galinya, maka kapal keruk yang digunakan untuk penambangan dapat dibedakan menjadi 3 (tiga), yaitu :

a. Multi bucket dredge yaitu kapal keruk yang alat-galinya berupa rangkaian mangkok (bucket).

b. Cutter suction dredge, yaitu kapal keruk dengan alat-gali berupa pisau pemotong yang menyerupai bentuk mahkota.

c. Bucket wheel dredge, yaitu kapal keruk yang dilengkapi dengan timba yang berputar (bucket wheel) sebagai alat gali.

\section{Potensi Dampak Lingkungan Hidup Dari Kegiatan Pertambangan}

1) Emas

Pada kegiatan pertambangan emas dilakukan dengan metode tambang bawah tanah (cut and fill) dan tambang terbuka (open pit). Adapun potensi dampak penting kegiatan pertambangan emas adalah sebagai berikut: 
a. Dampak Air Asam Tambang (AAT)

Di wilayah Tengah Kabupaten Halmahera Utara sungai yang berpotensi tercemar adalah sungai Ake Tiabo, sedangkan di wilayah Utara Kabupaten sungai yang berpotensi tercemar adalah sungai Ake Pacak, Ake Akerella, Ake Sahu dan Ake Pasawani.

b. Potensi berkurang atau punahnya biota endemik

Pada wilayah usaha pertambangan terdapat kawasan hutan lindung yang tumpang tindih terhadap kawasan hutan tersebut, sehingga metode penambangan terbuka pada wilayah di Kecamatan Malifut dan Kao berpotensi untuk melakukan pembukaan lahan, yang berpotensi terhadap berkurang atau punahnya spesies endemik berupa burung Bidadari dan Kakatua Putih.

c. Potensi pencemaran lingkungan akibat pengolahan emas

Ion sianida $(\mathrm{CN})$ mempunyai kemampuan menghambat kerja enzim dalam tubuh yang peka terhadap sianida (Anonymous, 1994).

\section{2) Nikel}

Kegiatan pertambangan nikel dengan metode tambang terbuka open cast berpotensi terjadinya dampak penting lingkungan hidup akibat kegiatan pembukaan lahan. Adapun potensi dampak penting tersebut adalah potensi pencemaran air.

Pertambangan dengan metode tersebut berpotensi terjadinya erosi sangat tinggi akibat adanya pembukaan lahan disamping karakteristik mineral nikel laterit (sedimen). Potensi pencemaran air terjadi pada saat musim hujan air mengalir melalui sungai musiman Desa Gonga dan masuk ke air laut sehingga air laut menjadi keruh.

\section{3) Mangan}

Kegiatan pertambangan dengan tambang terbuka (open cast) berpotensi terjadinya dampak lingkungan hidup. Adapun potensi dampak penting adalah adalah sebagai berikut:

a. Potensi Perubahan Bentang Alam

Perubahan bentuk topografi dan keadaan muka tanah (land-impact) di Pulau Doi Kecamatan Loloda Kepulauan dan Kecamatan Loloda Utara, dapat mengubah keseimbangan sistem ekologi bagi daerah sekitarnya. Pontensi dampak pencemaran air.

Pada proses pembukaan lahan berpotensi erosi dapat menyebabkan air menjadi tercemar. Adapun daerah aliran sungai berpotensi terjadinya pencemaran tersebut di antaranya sungai Ake Pacak, Ake Supu dan Ake Mela. Sungai pada daerah ini umumnya pendek-pendek yang apabila tercemar langsung masuk kelaut. Dampak eksternal penting mengancam terhadap pendapatan para nelayan di Kecamatan Loloda Utara. Daerah tangkapan ikan I (satu) beradada pada pantai kecamatan tersebut.

b. Potensi dampak dari Pengolahan Mangan.

Selain dampak yang ditimbulkan dari kegiatan penambangan, potensi dampak juga terjadi pada proses pengolahan bijih mangan yang menghasilkan tailing berbentuk slurry. Kandungan logam berat (Fe dan Mn) dapat berbahaya dengan konsentrasi yang tinggi. Salah satu dampak negatif tersebut berupa peningkatan limbah cairan tailing 
hasil pengolahan mangan apabila masuk ke badan sungai langsung masuk ke laut kecamatan Loloda Utara.

\section{4) Pasir Besi}

Adapun potensi dampak kegiatan pertambangan pasir besi dengan metode tambang terbuka dan kapal keruk adalah sebagai berikut:

a. Potensi terjadinya abrasi dan gelombang pasang ekstrim.

Abrasi selain menyebabkan gelombang ekstrim juga menyebabkan spesies endemik berupa burung Mamoa berkurang bahkan punah karena di daerah pantai Galela Utara merupakan tempat bertelur burung tersebut.

b. Potensi kelimpahan biota perairan.

Kegiatan penambangan pasir besi di pesisir pantai menyebabkan air laut di Kecamatan Loloda Utara dapat tercemar sehingga berpengaruh terhadap kelimpahan biota perairan.

c. Potensi berkurangnya produktifitas perikanan

Potensi produktifitas penangkapan ikan berkurang karena pada kegiatan penambangan mineral pasir besi berdekatan dengan daerah penangkapan ikan (DPI 1) dan daerah penangkapan ikan (DPI 2) yang menjadi daerah utama tangkapan ikan di Kabupaten Halmahera Utara.

d. Potensi dampak lingkungan dari pengolahan pasir besi.

Pada kegiatan pertambangan pasir besi tahapan proses pengolahan dapat berpotensi terjadinya pencemaran air laut akibat hasil pengolahan pasir besi berbentuk slurry.

\section{Arah Kebijakan Pengelolaan Lingkungan Hidup}

1) Emas

Adapun syarat usulan pengelolaan kegiatan penambangan mineral emas adalah sebagai berikut:

a) Membatasi luas bukaan sehingga ekosistem lokal terjaga yang menyebabkan spesies endemik berupa burung Bidadari dan Kakatua Putih tidak berkurang bahkan tidak punah

b) Pengelolaan air asam tambang dengan melakukan overburden management plan dan water management.

c) Limbah pengolahan bijih perlu diproses dengan detoksifikasi.

Ada dua tahap untuk mengurangi kandungan sianida dengan proses detoksifikasi. Fase pertama dari detoksifikasi dengan menggunakan sodium metabisulphat di dalam proses Inco detoksifikasi, akan dilakukan setelah limbah dipompa ke fasilitas penyimpanan limbah.

\section{2) Nikel}

Adapun syarat usulan pengelolaan kegiatan penambangan nikel adalah sebagai berikut:

a) Membatasi luas bukaan sehingga potensi erosi berkurang.

Kegiatan pembukaan lahan penambangan nikel dilakukan pada wilayah atau pada blok-blok mineral Nikel dengan kandungan kadar nikel yang tinggi. Setelah blok 
dilakukan penambangan blok tersebut direklamasi dan blok lainnya dilakukan penambangan, begitu seterusnya.

b) Pengelolaan air dengan melakukan Water Management.

c) Pengelolaan lahan bekas tambang.

\section{3) Mangan}

Adapun syarat usulan pengelolaan kegiatan penambangan mineral mangan adalah sebagai berikut:

a) Membatasi luas bukaan.

Penambangan dengan metode tambang terbuka berpotensi lahan menjadi kritis, dapat menimbulkan erosi, pencemaran air permukaan dan lain-lain, sehingga perlu membatasi luas bukaan agar lahan tidak terlalu lama dibiarkan.

b) Water Management

Penambangan dengan metode tambang terbuka akan memberikan dampak terhadap perubahan topografi di lokasi penambangan akibat adanya proses penggalian dan penimbunan. Hal ini tentu akan mempengaruhi kondisi hidrologi melalui perubahan catchment area. Pola aliran air permukaan akan mengalami perubahan yang akan mempengaruhi debit aliran pada sungai di catchment tersebut. Pembuatan kolam pengendapan, metode pemurnian air secara konvensional merupakan kombinasi dari tiga proses, yaitu koagulasi, flokulasi dan pengendapan.

c) Pengolahan Tailing

Sifat kimia dan fisik tailing sangat bervariasi biasanya sulit dimantapkan dan ditanami kembali. Oleh karena itu penelitian geoteknis dan non-teknis diperlukan agar tailing memenuhi kriteria sebagai berikut: Tidak mengakibatkan pencemaran, strukturnya stabil, serasi dengan bentang alam sekitarnya dan mempunyai kapasitas yang cukup untuk menampung seluruh tailing.

\section{4) Pasir Besi}

Adapun syarat usulan pengelolaan kegiatan penambangan pasir besi adalah sebagai berikut:

a) Pencegahan abrasi dengan cara sebagai berikut:

i. Penanaman mangrove, padang lamun

ii. Budidaya terumbu karang

iii. Pembuatan tanggul penahan ombak

b) Penambahan atau penetapan daerah perlindungan dan penguatan status konservasi untuk melindungi spesies endemik burung Mamua di kecamatan Galela Utara.

c) Membatasi perizinan eksploitasi pertambangan di sempadan pantai.

d) Pemberdayaan masyarakat nelayan.

Memberikan pelatihan budidaya perikanan seperti membuat kolam jaring terapung dan lain-lain. 


\section{KESIMPULAN}

Kesimpulan yang dapat ditarik dari penelitian ini adalah:

1. Arah kebijakan pengelolaan lingkungan hidup kegiatan pertambangan emas adalah sebagai berikut:

a. Membatasi luas bukaan sehingga ekosistem lokal terjaga yang menyebabkan spesies endemik berupa burung Bidadari dan Kakatua Putih tidak berkurang bahkan tidak punah.

b. Pengelolaan air asam tambang dengan melakukan overburden management plan dan water management.

c. Limbah Pengolahan bijih perlu diproses dengan detoksifikasi.

2. Arahan kebijakan pengelolaan lingkungan hidup kegiatan pertambangan Nikel adalah sebagai berikut:
a) Membatasi luas bukaan sehingga potensi erosi dapat berkurang.
b) Pengelolaan air dengan melakukan water management sehingga laut di desa Gonga Kecamatan Tobelo Timur tidak tercemar.
c) Pengelolaan lahan bekas tambang

3. Arah kebijakan pengelolaan lingkungan hidup kegiatan pertambangan Mangan adalah sebagai berikut:
a) Membatasi luas bukaan sehingga potensi erosi di Pulau Doi Kecamatan Loloda Kepulauan dan erosi di Kecamatan Loloda Utara serta Galela Utara dapat dikurangi.
b) Pengelolaan air dengan melakukan water management sehingga sungai Ake Pacak, Ake Supu dan Ake Mela dan laut di Kecamatan Loloda Utara, Galela Utara serta Loloda Kepulauan tidak tercemar.
c) Pengolahan tailing, pengelolaan tailing dapat dilakukan dengan lapisan air permanen, cladding dan capping.
d) Pengelolaan lahan bekas tambang.

4. Arah kebijakan pengelolaan lingkungan hidup kegiatan pertambangan pasir besi adalah sebagai berikut:
a) Pencegahan abrasi dengan dengan melakukan penanaman mangruve, budidaya terumbu karang dan pembuatan tanggul penahan ombak.
b) Penambahan atau penetapan daerah perlindungan dan penguatan status konservasi untuk melindungi spesies endemik burung Momua di Kecamatan Galela Utara
c) Membatasi perizinan eksploitasi pertambangan di sempadan pantai
d) Pemberdayaan masyarakat nelayan.

\section{DAFTAR PUSTAKA}

Asdak, Chay. 2012. Kajian Lingkungan Hidup strategis: jalan menuju pembangunan berkelanjutan. Gadjah Mada Unirversity press, Yogyakarta

BPS, 2013. Kabupaten Halmahera Utara Dalam Angka Tahun 2013

Hudson, L.Travis., Fox D Frederick dan Plumlee S Geoffrey. 1999. Metal Mining and the environment,Amerika,American Geological Institute 


\section{TECHNO: Vol. 07 ( 01) Mei 2018}

Hasyim, Wahab Abd. 2007. Keberlanjutan Kehidupan Sosial Ekonomi Masyarakat tanpa Tambang Nikel, Bogor, IPB

Katili dan Tjia, H.D. 1980. Geotectonic of Indonesia, a modern view, Department of Geology, Bandung Institute of Technology

Kendarsi dan Marjono. 1969. Bahan-bahan galian di daerah Provinsi Maluku, Dinas Eksplorasi, Direktorat Geologi, Bandung

Kisman. 2006. Eksplorasi pasir besi di daerah kecamatan Galela Utara, Pusat Sumberdaya Geologi Laporan Akhir Addendum Studi Kelayakan Sebagian Wilayah KK (25.852 Ha) Kencana 1, Kencana 2 dan Kencana Link, PT. Nusa Halmahera Minerals

Latifah siti, 2003, Kegiatan Reklamasi Lahan Pada Bekas Tambang, Universitas Sulawesi Utara.

Mitchell, Bruce, B. Setiawan, Rahmi Hadi Dwita. Pengelolaan Sumberdaya dan Lingkungan. Gadjah Mada Unirversity press, Yogyakarta

Meliani, Diah. 2011. Daya Dukung Lingkungan Kecamatan Rasau Jaya Berdasarkan Ketersediaan Dan Kebutuhan Lahan, Universitas Tanjungpura, Pontianak.

Republik Indonesia. 2009. Undang-Undang No. 4 Tahun 2009 tentang Pertambangan Mineral dan Batu Bara.

Republik Indonesia. 2009. Undang-Undang No. 32 Tahun 2009 tentang Perlindungan dan Pengelolaan Lingkungan Hidup.

Raden Ince, Pulungan, M. Saleh, Tamrin dan Dahlan Moh. 2010. Kajian Dampak Penambangan Batubara Terhadap Pengembangan Sosial Ekonomi dan Lingkungan di Kabupaten Kutai Kartanegara, Jakarta, Badan Penelitian dan Pengembangan Kementrian dalam Negeri

Republik Indonesia. 2008. Peraturan Pemerintah No. 26 Tahun 2008 tentang Rencana Tata Ruang Wilayah Nasional.

Republik Indonesia. 2008. Peraturan Pemerintah No. 2 Tahun 2008 tentang Jenis dan Tarif Atas Jenis Penerimaan Negara Bukan Pajak yang Berasal dari Penggunaan Kawasan Hutan Untuk Kepentingan Pembangunan di Luar Kegiatan Kehutanan yang Berlaku pada Departemen Kehutanan.

Republik Indonesia. 2008. Peraturan Menteri Kehutanan No. 56 Tahun 2008 tentang Tata Cara Penentuan Luas Areal Terganggu dan Areal Reklamasi dan Vegetasi untuk Perhitungan Penerimaan Negara Bukan Pajak Penggunaan Kawasan Hutan.

Rachmat, M. J. 1955. Peninjauan Cebakan Bijih Mangan di P. Doi, Urusan Geologi Ekonomi, Djawatan Geologi, Bandung

Spitz Karlheinz dan Trudinger John. 2009. Mining and the Environment from ore to metal.Taylor \& Francis Group.

Triadiyoga, Guruh Charismaputra. 2011. Geologi dan Hubungan Urat Kuarsa Terhadap Mineralisasi, Daerah Toguraci dan Sekitarnya, Kecamatan Kao, Kabupaten Halmahera Utara, Provinsi Maluku Utara

Suparmoko,M. 2008. Ekonomi sumber daya alam dan lingkungan suatu pendekatan teoritis,edisi 4 revisi, UGM, Yogyakarta

Yunianto, Bambang. 2008. Kajian Permasalahan sosial ekonomi Rencana Pengembangan dan Pengolahan Pasir Besi dipantai selatan Kulon Progo Yogyakarta,Bandung,Puslitbang Teknologi Mineral dan Batubara. 
Aliyusra Jolo \& Rudi S. Gautama. APL, Halmahera Utara, pertambangan, water management, tailing

Suparmoko. M. 2012. Ekonomi sumber Daya Alam dan Lingkungan (suatu pendekatan teoritis), Yogyakarta, UGM 